\title{
RE-DIMENSIONING THE POLISH-GERMAN BORDER AREA: POZNAŃ AS A CITY IN A TRANSNATIONAL COOPERATION SPACE
}

\author{
AlexANDER TÖLle \\ Adam Mickiewicz University, Institute of Socio-Economic Geography and Spatial Management, Poznań, \\ Poland
}

Manuscript received October 10, 2010

Revised version December 2, 2010

Tölle A., Re-dimensioning the Polish-German border area: Poznań as a city in a transnational cooperation space. Quaestiones Geographicae 29(4), Bogucki Wydawnictwo Naukowe, Poznań 2010, pp. 83-93, 3 maps, 3 tables. DOI 10.2478/v10117-010-0034-1, ISBN 978-83-62662-30-2, ISSN 0137-477X.

AвSTRACT. The declining importance of national policies and the economic level as a result of globalisation as well as European integration processes compels cities to become actors on the international stage and to define their own 'foreign policies', which may include the establishment of transnational alliances, networks, and cooperation territories. This will be discussed using Poznań as a case study. After the fall of the Iron Curtain the city had to integrate into traditional forms of international cooperation as well as new forms of transnational networking. Concerning the latter, the biggest challenge is the integration of Poznań into the strategic network of the Oder Partnership, which aims at creating a Polish-German cooperation space able to compete with other European regions.

KeY words: transnational cooperation space, strategic networking, city alliances, Poznań, Oder Partnership, Polish-German border area

Alexander Tölle, Institute of Socio-Economic Geography and Spatial Management, Adam Mickiewicz University, ul. Dzięgielowa 27, 61-680 Poznań, Poland; e-mail: atoelle@amu.edu.pl

\section{Introduction}

The development of border territories by cross-border cooperation is an aspect of European integration whose significance is constantly increasing. Regional disparities along borders be it economic activities, standards of living, institutional organisation, or questions of mentality and culture - highlight the existing differences within the European Union and therefore pose a special challenge to the overall aim of creating territorial cohesion. Hence regional and local ac- tors along state borders have learned to create cross-border cooperation structures and to profit from European funding opportunities in order to stimulate growth and development in different sectors (O'Dowd 2003; Kramsch \& Hooper 2004). In times of globalisation, however, the idea of cooperation across state borders is not limited to territorial entities physically close to the borders. Particularly cities, as economic hubs, have learned that the success of development policies increasingly depends upon the ability to deal with changes at the global scale and with deci- 
sions taken above the local, regional and even national levels. The decrease in the importance of national policies and the economic level compels cities to become actors on the international stage and to define their own "foreign policies", which may include the establishment of transnational alliances, networks, and cooperation territories. In the first part of this article this will be demonstrated by the city of Poznan, which in the last two decades after the fall of the Iron Curtain had to integrate into traditional forms of international cooperation and new forms of transnational networking. Concerning the latter, the biggest challenge is the integration of Poznań into the strategic network of the Oder Partnership, which aims at creating a Polish-German cooperation space able to compete with other European regions. Hence the second part of the article will analyse this new perspective of Poznan as a city in a cross-border macro-space by looking at the European and the Polish-German context, and by assessing the resulting problems and potentials.

\section{Poznań as an internationally linked metropolis}

The city of Poznań with currently 557,000 inhabitants - the core of an agglomeration with 944,000 inhabitants - is one of the most dynamic urban centres in Poland. Among the Polish cities, Poznan merits the title of an "exceptional city" (Parysek \& Mierzejewska 2006: 302) for its above-average performance in socio-economic development after 1990. This may be interpreted as an indicator of its ability to exploit its human and economic potential in the years of transformation. An important role is played by its geographic location at an intersection point between East-Central and Western Europe, i.e. halfway on the Warsaw-Berlin trajectory on which Poznan is the most important dynamic economic node (Domański 1999). The city is a key target area for foreign direct investment in Poland, with more than one-third of foreign direct investment since 1990 coming from Germany, and around another one-third from the UK, the USA, France and Japan (Stryjakiewicz et al. 2009: 36). The main investment sectors include industrial production (notably automotive, pharmaceutical and food industries) as well as trade and services (notably the business process outsourcing sector). Of outstanding importance is the Poznan International Fair, by far the biggest of its kind in Poland, organising e.g. 58 international fairs and nearly 1,700 conferences and conventions in 2008, including the UN Climate Change Conference with 12,000 participants. Hence, for numerous reasons, Poznan is undoubtedly in a good position to develop metropolitan functions of European significance (Stryjakiewicz et al. 2007).

Not surprisingly, therefore, Poznan today has international contacts in numerous forms, yet the history of their establishment is marked with the city's vicissitudinous past. Generally, with the emergence of the modern city in the era of strong national states, i.e. during the industrialisation process, municipalities quickly sought to form alliances in order to make their voice heard on the national stage. At the turn of the $19^{\text {th }}-20^{\text {th }}$ century, this resulted in the foundation of national city alliances - more often than not against the resistance of the national state. In consequence, the idea of exchanging experiences and promoting the concept of democratic local government beyond national borders led at an early stage to forms of cooperation between respective national city associations; the first organisation of this kind, the International Union of Local Authorities (IULA), was founded in 1913. With the Polish state nonexistent at that time and Poznan a part of the Prussian-German partition area, the city first became represented by the German Association of Cities (Deutscher Städtetag) founded in 1905, which even held its general assembly in Poznań in 1911. When the Polish state became reinstated after the First World War, its cities organised into the Association of Polish Cities (APC, Związek Miast Polskich). Liquidated under the German occupation during the Second World War, the APC was also unable to be reinstalled afterwards as there were no self-ruling municipalities in the states behind the Iron Curtain. However, the APC, now with some 300 members, was re-founded in 1990, and the city of Poznan plays a key role in its activities: it is the alliance's seat, and its mayors presided over the APC in 1991-98 and have done so again since 2003. The APC represents its member cities also at the EU level, at which the articulation of local and regional interests became increasingly 
Table 1. Twin cities of Poznań.

\begin{tabular}{|c|c|c|c|}
\hline City & Population & Country & Year of twinning \\
\hline Brno & 400,000 & Czech Republic & 1966 \\
\hline Hannover & 524,000 & Germany & 1979 \\
\hline Jyväskylä & 80,000 & Finland & 1979 \\
\hline Toledo & 650,000 & USA & 1991 \\
\hline Assen & 61,000 & The Netherlands & 1992 \\
\hline Pozuela de Alarcon & 79,000 & Spain & 1993 \\
\hline Shenzen & $4,000,000$ & China & 1993 \\
\hline Nottinghamshire (County) & $1,000,000$ & UK & 1994 \\
\hline Nablus & 150,000 & Palestinian National Authority & 1997 \\
\hline Kharkov & $1,500,000$ & Ukraine & 1998 \\
\hline Rennes & 210,000 & France & 1998 \\
\hline Györ & 128,000 & Hungary & 2008 \\
\hline Kutaisi & 190,000 & Georgia & 2009 \\
\hline
\end{tabular}

Source: Poznań Mayor's Office.

important in the course of (first West) European integration. In this context, today the main institutions within the EU structure are the Council of European Municipalities and Regions (CEMR, whose predecessor was founded in 1951) as an umbrella organisation of national associations, the Congress of Local and Regional Authorities of Europe (CLRAE), and the Committee of the Regions (CoR) consisting of representatives - whose number dependents upon the respective national population figures - of local and regional authorities and associations. So, with the increased significance of the European Union, municipalities have become integrated into its hierarchical political decision-making structures, and Poznań is linked to these structures through a national city alliance.

When looking at traditional forms of international cooperation between cities, one cannot overlook city twinning, even though its initial motivation was limited to fostering international understanding and friendship at the local level after the two world wars. At the time of centralstate communist rule, this was the only - but also restricted - possibility for any municipality to link to the international world. So at the end of the 1980s Poznan was only linked to Brno in the "communist brother state" of Czechoslovakia, and - having taken advantage of a rare window of opportunity at the end of the 1970s - to two West European cities. Since then, four of the ten additional partnership agreements signed so far have been with municipalities from the "old" EU states and three with East-Central European cities, two of the latter in countries potentially interested in future EU membership. Poznan's history of twinning, therefore, somewhat reflects the classical pattern (see Table 1): it is a typical characteristic of city twinning that its focus is not necessarily on cooperation projects and therefore on finding "fitting" partners, but "on the mutual acquaintance of communities from various linguistic, geographical and cultural zones" (Kaczmarek 2006: 66). Concerning partnerships between European cities, there is often an emphasis on pro-European inclinations, since 1990 notably in the form of linking East-Central European cities with those from the "old" EU countries. However, the forms of cooperation between Poznan and its twin cities are evidently shifting from conventional partnership activities (e.g. a cultural or youth exchange) to project-focused cooperation forms. This may best be demonstrated by the European Cooperation Forum of the three twinned cities of Rennes, Hannover and Poznań, inaugurated in 2007. This venture - explicitly inspired by the political construct of the French-GermanPolish Weimar Triangle as a pillar of European integration - involves a trilateral annual meeting seeking to foster cooperation in fields of relevance for cities in an integrating Europe, e.g. in 2009 the topic was City and Science. Another example is the creation of the Poznan - Ille-et-Vilaine Foundation, which - based on the twin partnership between Poznań and Rennes (the capital of the Ille-et-Vilaine Département) - is to support not only cultural, but also scientific and economic cooperation between the two city regions. 


\section{Poznań as a transnational networked city}

In her analyses of transnational city networks Kern (2001: 111) concludes that "the international city associations are more and more evolving into transnational city networks, while traditional city partnerships are being complemented or replaced by short-term and project-focused city cooperation." It has just been argued that the latter aspect is true for Poznań, and it will now be claimed that this is also the case for the city's transnational engagement. In general, the cooperation of cities in strategic transnational networks can also be interpreted as a result of the diminishing role of the national state level, with the important point here being the far-reaching restructuring process of socio-economic and spatial relations due to the globalisation of economic activities. The motivation for organising into city networks can be summed up in three functions: the representation of the members' interests, information and advice for the members, and an exchange of experiences between the members. In that there appears to be no fundamental difference from conventional city associations; however, there is a clear shift of priorities to be observed: while representation of interests and lobbying still plays an important role, the aspect of learning in networks, especially in thematically specialised networks, becomes the key function (Kern 2001). This increase in transfer functions may be seen as the crucial difference between conventional international city associations and transnational city networks. The general appeal of networking lies in its ability to combine strengths and to balance weaknesses in order to compete in a globalising world (Knieling \& Kunzmann 2005). Strategic networks are characterised by loose relationships between the participating partners, and their informal and nonbinding character makes it difficult to steer them and to produce tangible results. Yet there are also decidedly positive points of networks (Payer 2008): each partner expects to benefit through participation in it (benefit-orientation), and this benefit is to be a product of the fact that each partner brings in his relevant capabilities or resources (reciprocity). The surplus value of networking is supposed to result from the adding up of individual strengths (strengths-orientation), yet as no partner is expected to bring in more than his relevant strength, he is not at risk as a whole if anything goes wrong. i.e. he keeps his full autonomy (partial interconnectivity). Due to these four characteristics networks have become of special interest as an informal tool for addressing common development tasks, in particular under conditions in which no agreed or routine procedures exist (Morgan et al. 2000). City networks can be put into two categories: networks that - similar to conventional city associations - represent their members while defining e.g. the size or geographical location of potential members, without limiting their work to any specific topics (e.g. the EUROCITIES with 140 members in 36 countries or the Union of Baltic Cities, UBC, with 106 members in 10 countries), and networks that focus on certain cooperation topics (e.g. the International Council for Local Environment Initiatives, ICLEI, with 1,054 members worldwide).

With transnational city networks having become the key instrument of lobbying, exchanging experiences and getting information and advice, it is only natural that Poznan - having regained the right to local self-government in 1990 - has engaged in several ventures of transnational networking. A key role is played by the city's full membership in the mentioned EUROCITIES network. Representing cities with more than 250,000 inhabitants, it focuses on lobbying at the EU level with the aim of influencing legislation and strengthening local government on the one hand, and on providing a platform to share knowledge, ideas and experiences between its member cities on the other hand. While not restricted to specific policy areas, the network, led by an executive committee, concentrates on certain fields by operating through seven thematic forums: cooperation, culture, economy, environment, knowledge society, mobility, and social affairs. The forums are subdivided into different working groups which address specific issues and coordinate activities, including the drafting of the EUROCITIES position papers. Forums and working groups are open to all member cities, and Poznan cooperates in the Knowledge Society and the Economic Development forums, as well as in the Cohesion Policy, Economic Migration, and Urban Regeneration working groups of the latter. In general, this choice of activity fields reflects the 
two main areas on which Poznań focuses its network activities, i.e. knowledge and European city policy targets. Concerning the former, Poznan which pursues a policy of making science and innovation a main constituent of city development under the slogan of "Know-how City" - is also linked through EUROCITIES to the European Urban Knowledge Network, an initiative by 17 EU member states (including Poland) and the European Commission aiming to facilitate the exchange of demand-driven knowledge and experiences in urban issues between decision makers and experts. The emphasis on EU integration policies in turn is represented by the city's engagement in the Strasbourg Club. This network, founded in 2003 on an initiative of the mayor of Strasbourg, was to link 35 main urban centres of the then future EU member states with the EU Parliamentary capital. Its action fields include training in the use and knowledge of EU funds, an exchange of best practice in transport and logistic issues, as well as exchange programmes for students and artists. Two other specialised fields of interest are represented by the WHO Healthy Cities Network, which promotes the integration of health and health equity into local policies. Poznan actively participated in its Phase IV, dedicated to the issue of tackling the determinants of health, sustainable development, and participatory and democratic governance. Poznań is also a member of Mayors for Peace. This initiative, which was started by the mayor of Hiroshima in 1982 and has currently nearly 4,000 member cities in more than 140 countries, promotes a total abolition of nuclear weapons.

\section{Poznań as a transborder space city}

From a historical perspective, Poznań was characterised for centuries by its borderland location between the Polish and German populations (Serrier 2005). During the $9^{\text {th }}$ century the tiny settlement on the river Warta developed into a fortified main seat of the Piast rulers and thus became the cradle of Polish statehood and Christianity. In the $13^{\text {th }}$ century Poznań was granted city rights under the Magdeburg Law. Newly planned, the town expanded onto the left bank of the Warta, which brought a significant number of German settlers to it as part of the medieval German eastward expansion. However, this living together of different ethnic groups did not become a dominant issue until the rise of nationalism and nation states at the end of the $18^{\text {th }}$ century. With Poznan becoming part of Prussia (and thus later of Imperial Germany) in the course of elimination of the Polish state in the so-called Polish Partitions, the city and its surrounding region became the theatre of a steadily hardening Germanisation policy in the $19^{\text {th }}$ century, which the Polish majority increasingly defied. When after the re-establishment of the Polish Republic Poznan found itself close to its western border, this atmosphere of conflict and suspicion continued to prevail and made any form of cross-border cooperation in the inter-war period illusive. As a result of the Second World War and its atrocities committed by Nazi Germany, the Polish state borders were shifted to the West and the German population expelled, thus ending abruptly Poznańs history as a borderland city.

It is from the perspective of this complicated legacy that modern Polish-German cross-border contacts have to be interpreted. After the war such contacts were virtually non-existent between East Germany and the Polish People's Republic, so it is justified to speak of a "zero hour" when referring to the fall of the Iron Curtain in 1989. Cross-border activities unfolded notably during the early 1990s in the newly-created Euroregions and in the "twin cities" on the Oder and the Neisse divided by the river border. However, there was no shift towards a broader perspective of cross-border cooperation during the 1990s, even though there existed since 1995 the "Spatial Leitbild for the Polish-German Border Area", a product worked out by the joint Polish-German Ministerial Commission for Spatial Planning. The defined objectives - a reduction of separating effects, a reduction of socio-economic differences, particularly concerning the quality of life, and consolidation of the functionality and competitiveness of the major economic development centres on both sides - were never turned into active policies. So the "Actualisation of the Spatial Leitbild for the Polish-German Border Area" approved in 2002 fell short of being an update based on the analyses of its predecessor (Ciok et al. 2008) and stays in line with its general direc- 
tions. A remarkable change, however, is the enlargement of what is defined as the border area: the initial area, i.e. basically the territory covered by INTERREG A with Szczecin as the only large urban agglomeration, has become the "immediate border area", while the "border area" now extends to the cities of Poznan, Wrocław, Dresden, and Berlin (see Map 1). This definition was the basis for an initiative in the same year by highranking Polish and German planning officials to create a transnational economic space in the pentagonal area between the said five cities under the title of "The German-Polish House" (Selke 2004: 14). While this initiative in the end failed to get political support, mainly because of fears concerning a potentially too large a focus on the five nodes of the net and a disregard of the "loops" between them (Kohlisch 2008: 110), it appears to have prepared the ground for new thinking.

In that, an important factor is the extension of territorial self-government in Poland - including notably the possibility to get involved in transnational cooperation - to the regional level (Tölle 2010a). This is a result of the 1999 reform of the country's territorial division creating 16 voivodeships, but it expresses itself also in the constant debate on creating metropolitan areas in Poland since the introduction of this notion into Polish

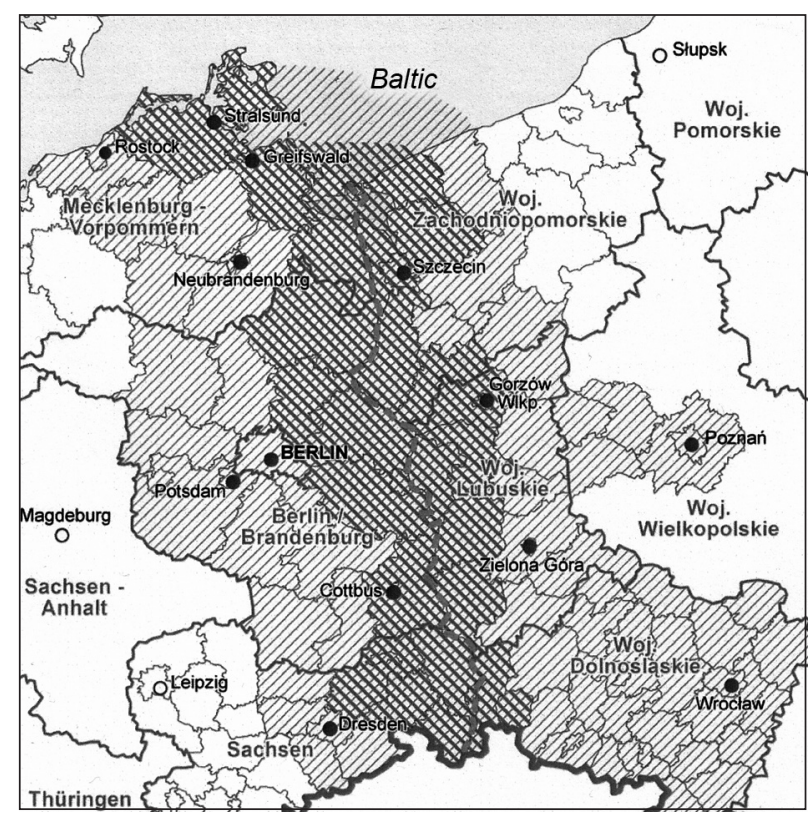

Map 1. Polish-German border area (light grey) with immediate border area (dark grey).

Source: Actualisation of the Spatial Leitbild for the Polish-German border area 2002 planning legislation in 2003. While e.g. in Germany eleven metropolitan regions have been defined at the federal state level (including the Capital Region of Berlin and Brandenburg and the Saxon Triangle, i.e. the agglomerations of Dresden, Leipzig, and Chemnitz-Zwickau), in Poland a draft bill designating twelve metropolitan areas has not been passed so far. There are, however, multiple local-level initiatives to create metropolitan cooperation structures. In Poznań, they manifest themselves in the 2007 agreement to create an Agglomeration Council (Rada aglomeracji), in which presently the city of Poznan, the poviat of Poznań, and the latter's 17 communes (plus three outside the poviat) with a total of 944,000 inhabitants are represented by its respective mayors or chief administrators. The overall aim of this institution is to secure information exchange and to prepare joint action at the metropolitan level in the fields of marketing and public investment, public services and transport, education, health, and spatial development.

The pressure at the national as well as the local level to create metropolitan structures derives to a significant degree from the spatial development policy of the European Union, as manifested in the 2007 Territorial Agenda of the European Union, TAEU, as a follow-up document of the 1999 European Spatial Development Perspective, ESDP. This policy's objectives are territorial cohesion and polycentric development, putting a special emphasis on the development of the European metropolitan regions, which account for the majority of population and economic potential of the EU (Dühr et al. 2007). In accordance with the principle of achieving a balanced spatial development of the European regions, as well as the goal of fostering the global competitiveness of the EU as a whole, the target is to create dynamic centres well-integrated into the global economy, especially outside the EU core area (the pentagonal area between the metropolitan areas of London, Paris, Milan, Munich and Hamburg). In addition, the implementation of the EU's territorial objectives is to rely to a significant degree upon sophisticated forms of voluntary cooperation between regional and local entities, which are to become "key actors" (Ahlke et al. 1999: 701); cross-border and transnational cooperation is of especial importance here. 

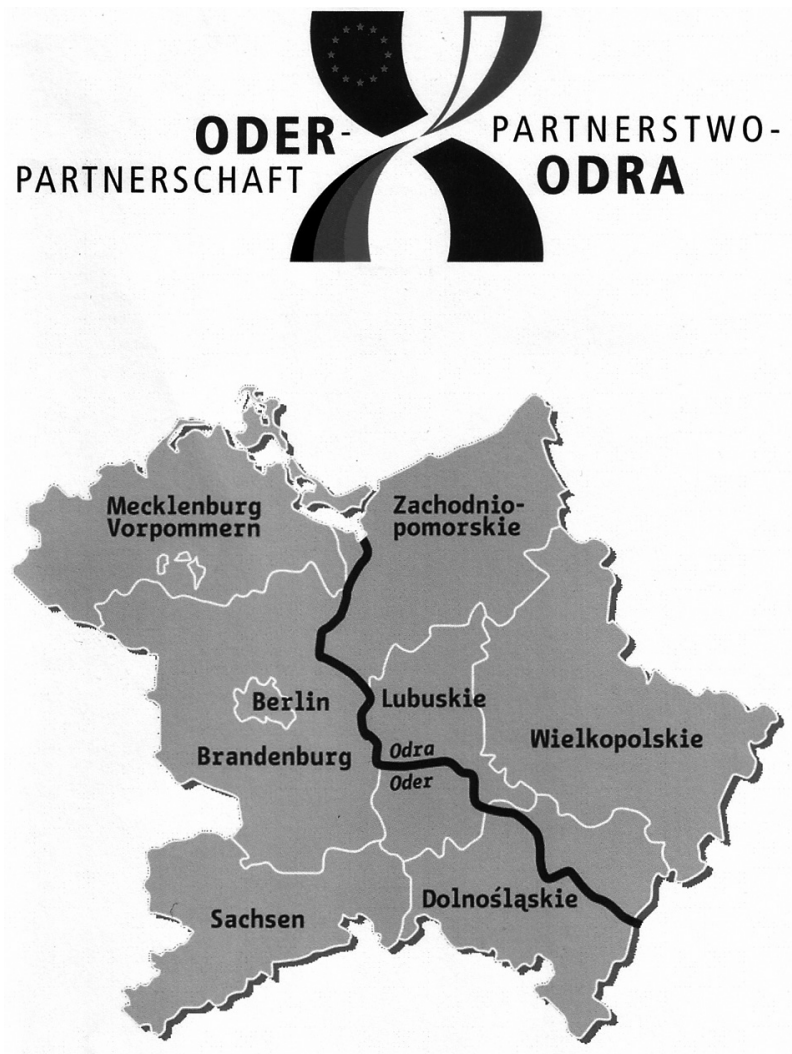

Map 2. The Oder Partnership cooperation space. Source: www.oder-partnerschaft.eu.

It is in this context that the idea of linking the main urban economic centres on both sides of the Oder river by creating a macro Polish-German transborder cooperation space is to be seen. The initiative was taken by the city state of Berlin, whose failure to return to its "Golden Age" of the 1920s as a roaring global metropolis (Tölle 2010b), manifesting itself in a precarious socio-economic situation, led to a profound re-evaluation of the potential deriving from the city's proximity to the Polish border. This attitude was reinforced even more by Poland becoming a member state of the European Union in 2004 and its access to the Schengen zone in 2007, which meant a significant loss of the dividing effect of the PolishGerman border. So in 2006, the city state of Berlin staged a conference on economic cooperation attended by senior political and administrative representatives of the German federal states of Brandenburg and Mecklenburg-Cispomerania (Mecklenburg-Vorpommern), of the voivodeships of Lower Silesia, Lubuska Land, West Pomerania, and Wielkopolska, as well as of the latter's capital cities of Wrocław, Gorzów Wielko- polski / Zielona Góra, Szczecin, and Poznań. The participants agreed to engage in forming an "innovative, knowledge-based economic area" at a macro-scale, able to compete with other European regions. Within this strategic network called the Oder Partnership (see Map 2) - which was joined by the federal state of Saxony in 2008 - cooperation is to focus on three sectors: firstly, innovation, technology and small and mediumsized enterprises; secondly, tourism; and thirdly, transport and logistics, notably improvements of cross-border connections. The Oder Partnership is based on the example of macro cooperation spaces, such as the Greater SaarLorLux Region, the Oresund Region, or the Central European Region CENTROPE, all of them transnational networks contributing to the emergence of functional cross-border regions. In such regions, networking in specified action fields - again with a strong connection to EU funding objectives has led to common spatial and socio-economic development policies. The action fields of transnational strategic networks in European cooperation areas may be summarised as enhancing economic cooperation, especially between SMEs, lobbying at the European and respective national levels, implementing "hard" projects, notably in the field of infrastructure and transport connections in the cooperation area, exchanging best practice experiences, notably in the sense of "learning networks", and working out transnational marketing and tourism strategies (see $\mathrm{Ku}$ jath \& von Schlippenbach 2002, Knieling \& Kunzmann 2005).

Thus, in the context of modern strategic networking, Poznan has become a city in a transborder macro-space. The Oder Partnership is essentially based on cooperation between regions, i.e. federal states and voivodeships, and so far German city municipalities (apart from Berlin, as the city has the status of a federal state) are not represented, while on the Polish side all regional capitals, including Gorzów (125,000 inhabitants) and Zielona Góra $(117,000)$, are members of the partnership. Nevertheless there is no doubt that the economic hubs of this macro-space, i.e. the metropolitan regions of Berlin, Dresden, Szczecin, Wrocław, and Poznan, are at the heart of the economic growth processes to be generated (see Table 2). 
Table 2. The Main partner cities of Poznań in the Oder Partnership

\begin{tabular}{|c|c|c|c|}
\hline City & City population & Metropolitan area population* & Distance from Poznań \\
\hline Berlin & $3,420,000$ & $5,960,000$ & $280 \mathrm{~km}$ \\
\hline Dresden & 510,000 & 750,000 & $330 \mathrm{~km}$ \\
\hline Szczecin & 410,000 & 760,000 & $235 \mathrm{~km}$ \\
\hline Wrocław & 640,000 & $1,000,000$ & $165 \mathrm{~km}$ \\
\hline
\end{tabular}

Source: for Germany, Federal Statistical Office, Wiesbaden; for Poland, Central Statistical Office, Warsaw, 2008.

*The metropolitan areas included here are the officially defined territories of the Capital Region of Berlin and Brandenburg, the Ballungsraum (Agglomeration) of Dresden, and the Agglomeration of Wrocław. The Szczecin Metropolitan Area is defined here (simplifying) as consisting of the city of Szczecin and the four poviats of Goleniów, Gryfino, Police, and Stargard Szczeciński.

The importance for Poznań of networking with these economic centres derives from the fact that, despite its good performance in national terms, from a European perspective Wielkopolska belongs to socio-economically deprived regions (see Table 3), as do the other regions in the Oder Partnership, however, including the German partners. While the inclusion of socioeconomically weaker partners in cooperation structures is a characteristic of numerous existing partnerships, it may be seen as problematic that the Oder Partnership - in contrast e.g. to the Greater Region with Luxembourg or CENTROPE with Vienna - has no strong economic centre of European standing. The Berlin Capital Region may be a heavyweight due to its sheer size, yet because of its relative weakness it is unlikely to take over the role of a single development engine. From this perspective the importance of a network in which the strengths of all economic centres - including Poznan in particular and the other metropolitan areas - will be identified and put to good use, becomes apparent (Tölle 2010a). In addition, the chosen cooperation space of the Oder Partnership - consisting of four federal states and four voivodeships - is unusually large. Its territory as well as its population is roughly more than twice the size of the Greater Region and more than three times that of the Central European Region. To tackle the unavoidable drawbacks, such as a lower degree of commitment of the partners, higher transaction costs and reduced communication at a personal level, personal contacts - on which networks as social infrastructure rely - can best be maintained by Poznan and the other urban nodes. This, however, will require a substantial improvement of rail and road links, which are of a poor standard, notably across the border.

\section{Transborder activities}

At the political level, the Oder Partnership has a sound basis, and the inaugural Berlin conference has been continued by regular political summit meetings. Poznan hosted the 2008 meeting that was of special importance in two respects: firstly the federal state of Saxony started to get involved in the Partnership, and secondly the meeting was attended by officials from the Polish and the German Foreign Office, which meant the integration of the Oder Partnership into national foreign policies. Organisational structures of the Oder Partnership are reduced to a minimum with practical work being done in "network rounds" on the

Table 3. Key figures of the metropolitan regions in the Oder Partnership (NUTS-2) in the EU perspective.

\begin{tabular}{|c|c|c|c|}
\hline \multicolumn{2}{|c|}{ Metropolitan region } & $\begin{array}{l}\text { Deviation from EU-27 unemploy- } \\
\text { ment rate in percent points in } 2007\end{array}$ & $\begin{array}{l}\text { GDP per capita in PPS in } \% \text { of EU-27 } \\
\text { average in } 2006\end{array}$ \\
\hline \multicolumn{2}{|c|}{ Poznań (Wielkopolska) } & +1.3 & 55.1 \\
\hline \multicolumn{2}{|c|}{ Szczecin (West Pomerania) } & +4.5 & 47.7 \\
\hline \multicolumn{2}{|c|}{ Wrocław (Lower Silesia) } & +5.7 & 56.0 \\
\hline \multirow{3}{*}{ Berlin } & City State of Berlin & +9.3 & 97.3 \\
\hline & Brandenburg Northeast & +8.1 & 75.5 \\
\hline & Brandenburg Southwest & +5.8 & 85.0 \\
\hline \multicolumn{2}{|c|}{ Dresden (Administrative District) } & +6.3 & 87.4 \\
\hline \multicolumn{2}{|c|}{ Germany } & +0.2 & 115.7 \\
\hline \multicolumn{2}{|r|}{ Poland } & 0.0 & 52.3 \\
\hline
\end{tabular}

Source: own compilation based on EUROSTAT. 
three main topics of innovation, technology and SMEs (coordinated by the Berlin Senate for Economics), tourism (coordinated by the Brandenburg Ministry for Economics), and transport (coordinated by the Public Transport Association of Berlin \& Brandenburg). This is complemented by a so-called "coordination tandem", with the Marshal Office (the unit for international cooperation) in Szczecin being responsible for activities on the Polish side, and the Berlin Senate for Economics on the German side. In addition, there is also an external network management assigned by the Berlin Senate consisting of three consultancies. In Poznan, the mayor's plenipotentiary for institutional relations is responsible for the city's activities in this network.

Poznań and its region has profited from some of the first activities of the Oder Partnership. 13 institutions from Wielkopolska, including 8 from Poznań itself, have contributed to create a bilingual Polish-German Internet platform, EUNOP (EU-Net Oder Partnership). As a contact board, it offers information to Polish and German SMEs as well as research and economic institutions about non-profit institutions specialising in EU institutional and funding matters in the partner regions. Also targeting the promotion of SME cooperation is the JOSEFIN project, which aims at creating network structures for SMEs in all partner regions of the Oder Partnership (with the exception of Saxony) as well as in the Baltic states, Sweden and Norway. Based on its predecessor, TEICONet, it seeks to open up financial opportunities for transnational SME cooperation, including the coaching of enterprises and the creation of appropriate funding products. A further field of cooperation is to be opened up by the joint initiative of the Marshal Office of Wielkopolska and of the Berlin Senate for Economics, which organised the Economic Forum Berlin - Wielkopolska 2010 in Berlin in June that year. Its aim was to extend innovative cluster strategies across the border, especially by linking firms from the growth sectors of information and communication technologies and from creative and design industries.

In the second important cooperation field that of transport and logistics - regular roundtable talks inaugurated in 2006 helped to enhance cross-border rail connections by better coordination of timetables and special ticket offers on both sides of the border. They also led to common lobbying strategies in order to implement "hard" infrastructural projects, especially with the support of EU funding (Kohlisch 2008). This concerns the improvement of rail connections between Berlin and Szczecin as well as Wrocław, but also the integration of Berlin into the planned Polish highspeed train network from Warsaw via Łódź to Poznań and Wrocław (the so-called Y-concept, see Map 3). This shared interest of Poznań and its region as well as of the Berlin Capital Region was highlighted in November 2009 when the voivodeship staged a conference in Poznan on the chances and repercussions of the high-speed train network for Wielkopolska. The invitation of numerous representatives from the German side may well help to turn this meeting into a starting point for a common lobbying strategy in order to get this major European transport venture supported at the EU and both national levels.

Another aspect concerns an exchange of experiences in the sense of learning networks. In 2009, a Berlin Day in Poznań organised at Adam Mickiewicz University served as a platform to discuss policies concerning economic strategies, city planning, transport, and regional cooperation in the Capital Region, and a similar venture, a Poznań Day, is due to take place in Berlin. One important discussion point was the new airport, Berlin Brandenburg International, due to open in June 2012, whose integration into the region's spatial and economic structure - as well as in the long run into a transborder transport concept is of special interest for the Poznan region, cur-

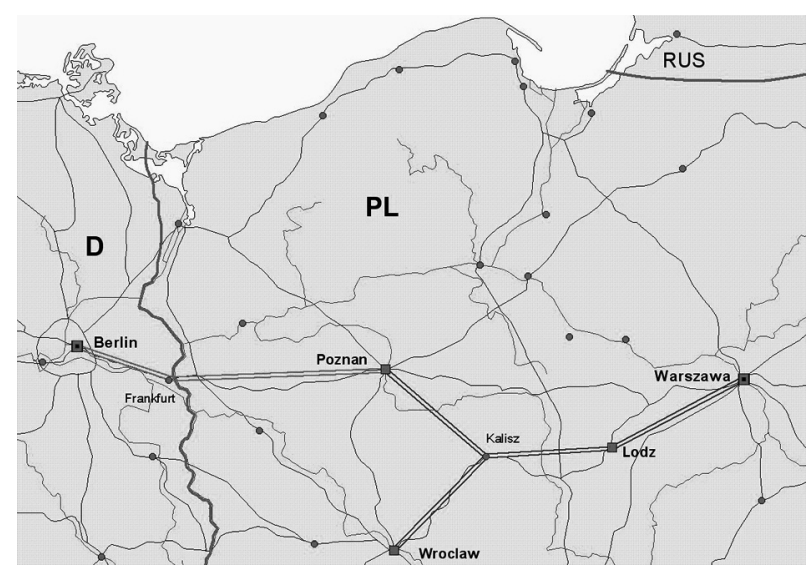

Map 3. The planned Polish high-speed train network (the Y-concept). Illustration by Bruno Aust. 
rently upgrading and extending the city's Ławica airport.

\section{Conclusion}

The city of Poznan has acknowledged the challenge of becoming integrated into network structures in a globalising world. Its main motives do not differ from those generally observed in European cities: to get the city's interests represented, to obtain relevant information, and to exchange best practice experiences. With the last point - the aspect of learning - becoming ever more important, after the fall of the Iron Curtain the city has simultaneously become involved in traditional city association work and city twinning, as well as in network activities. A new challenge still in its set-up stage, however, is the integration of the city into a strategic network within a transnational Polish-German macro cooperation space. While the city has seized this opportunity from its very beginning and become an active member at the political superstructure level, the degree of involvement at the working level is still modest - a fact so far true, however, of the whole of the Oder Partnership. With Poznan located outside the immediate border area, and therefore outside the reach of classical INTERREG A-funded cross-border ventures, positive effects of becoming a "border-area metropolitan region" are bound to emerge only indirectly. Yet when judging the few ventures so far implemented within this partnership, one may acknowledge its general compatibility with the European spatial strategies and funding structures, as well as its aspiration to join forces and strengths in order to create growth in a socio-economically poor - from a European perspective - macroregion. Undoubtedly, Poznan and the other four economic, demographic, cultural and transport hubs of this cooperation area will play a key role in this process, and in turn have the biggest potentials to profit from it. While self-identification as a city in the Polish-German border area may be much more difficult for historical reasons than in other European transborder regions, time, global pressure, European stimuli, and perhaps soon a perceptible economic success may help to lead to thinking in new socio-economic and spatial dimensions.

\section{References}

Ahlke B., Göddecke-Stellmann J., Illés I. \& Schön K.P., 1999. Regionen und regionale Zusammenarbeit in Europa (Regions and regional cooperation in Europe). Informationen zur Raumentwicklung 9/10: 687-710.

Ciok S., DoŁzbŁasz S., LeśniaK M. \& RaczyK A., 2008. Polska - Niemcy. Wspótpraca i konkurencja na pograniczu (Poland - Germany. Cooperation and competition in the border area). Wrocław, Wydawnictwo Uniwersytetu Wrocławskiego.

DOMAŃSKI R., 1999. Poznań as a centre of attraction on the trajectory Berlin - Warsaw. Intervening opportunities. In: Kukliński A. (ed.), The changing map of Europe. The trajectory Berlin - Poznań - Warsaw. Rewasz, Warsaw: 135-139.

DüHr S., Stead D. \& Zonneveld W., 2007. The Europeanization of spatial planning through territorial cooperation. Planning, Practice E Research 22 (3): 291-307.

KaczmareK T., 2006. Transborder co-operation and interterritorial partnership of Polish communes and regions. Quaestiones Geographicae 25: 61-71.

KERN K., 2001. Transnationale Städtenetzwerke in Europa (Transnational city networks in Europe). In: Schröter E. (ed.), Empirische Policy- und Verwaltungsforschung. Lokale, nationale und internationale Perspektiven. Leske + Budrich, Opladen: 95-116.

KNIELING J. \& KunZMANN K.-R., 2005. Räumliche und funktionale Netze (Spatial and functional nets). In: Handwörterbuch der Raumordnung, Akademie für Raumforschung und Landesplanung, ARL, Hannover: 704-709.

KoHlisch T., 2008. Regional Governance in europäischen Regionen: Eine empirische Analyse der transnationalen Verbünde Großregion / La Grande Région und Oder-Partnerschaft / Partnerstwo Odra (Regional Governance in European regions: An empirical analysis of the transnational groupings of the Greater Region and Oder Partnership). Lit, Münster.

Kramsch O. \& Hooper B., 2004. Introduction. In: Kramsch O., Hooper B. (eds), Cross-border governance in the European Union. Routledge, London \& New York: 1-21.

KuJATH H.J. \& vON SCHLIPPENBACH U., 2002. Europäische Verflechtungen deutscher Metropolregionen als Herausforderung für Politik und Wirtschaft (European linkages of German metropolitan regions as a challenge for politics and the economy). Informationen zur Raumentwicklung 6/7: 381-392.

Morgan B., Brooksbank D. \& Connolly M., 2000. The role of networking in the new political economy of regional development. European Planning Studies 8 (3): 319-336.

O'DowD L., 2003. The changing significance of European borders. In: Anderson J., O’Dowd L. \& Wilson T. (eds), New borders for a changing Europe. Cross-border cooperation and governance. Frank Cass, London \& Portland, Or.: 13-36.

Parysek J.J. \& Mierzejewska L., 2006. City profile: Poznań. Cities 23 (4): 291-305.

PAyer H., 2008. Netzwerk, Kooperation, Organisation - Gemeinsamkeiten und Unterschiede (Network, cooperation, organisation - similarities and differences). In: Bau- 
er-Wolf S., Payer H. \& Scheer G. (eds), Erfolgreich durch Netzwerkkompetenz. Handbuch für Regionalentwicklung. Springer, Wien \& New York: 5-22.

Selke W., 2004. Deutsch-Polnisches Haus: Auf dem Wege zu einer grenzüberschreitenden Wirtschaftsregion in Mitteleuropa? (German-Polish house: Towards a cross-border economic region in Central Europe?). In: Stoll M. (ed.), Strukturwandel in Ostdeutschland und Westpolen. ARL, Hannover: 1-17.

SerRIER T,. 2005. Provinz Posen, Ostmark, Wielkopolska. Eine Grenzregion zwischen Deutschen und Polen 1848-1914 (A border region between Germans and Poles 1848-1914). Herder-Institut, Marburg.

Stryjakiewicz T., Kaczmarek T., Męczyński M., Parysek J.J. \& Stachowiak K., 2007. Poznan faces the future. Pathways to creative and knowledge-based regions. ACRE report 2.8, Amsterdam.

Stryjakiewicz T., Tölle A., KudŁak R., Motek P., RóżalskaKusza A. \& WDowicka M., 2009. Profile miejskie - Poznań / Städteprofile - Posen (City profiles - Poznań). Bogucki Wydawnictwo Naukowe, Poznań.

TÖLLE A., 2010a. Transnational co-operation in strategic networks in Polish metropolitan areas. In: Churski P. \& Ratajczak W. (eds), Regional development and regional policy in Poland: First experiences and new challenges of the European Union membership. Studia Regionalia 27 (II), KPZK PAN, Warszawa: 106-120.

Tölle A., 2010b. Urban identity policies in Berlin: From critical reconstruction to reconstructing the Wall. Cities. 